\title{
THE ROLE OF COAL COMBUSTION PRODUCTS IN MANAGING THE BIOAVAILABILITY OF NUTRIENTS AND HEAVY METALS IN SOILS
}

\author{
B. Seshadri ${ }^{1,2, *}$, N.S. Bolan ${ }^{1,2}$, R. Naidu ${ }^{1,2}$ and K. Brodie ${ }^{3}$ \\ ${ }^{1}$ Centre of Environmental Risk Assessment and Remediation; ${ }^{2}$ CRC CARE, University of South \\ Australia, Mawson Lakes, SA. ${ }^{3}$ Flinders Energy, South Australia. \\ *Corresponding author: Balaji.Seshadri@potgrads.unisa.edu.au
}

\begin{abstract}
Coal provides the primary source of energy for many countries including Asia, South America, North America and Europe, and large quantities of waste products are produced during the combustion of coal in coal-fired power stations. This review paper gives an overview of the various types of coal combustion products (CCPs) and their utilization in various sectors, with a particular emphasis on the role of CCPs in managing the bioavailability of nutrients and heavy metals in relation to enhancing soil chemical fertility and mitigating metal contaminated soils. Currently, CCPs are used extensively in agricultural and construction industries. In agricultural industries, they are used primarily as an amendment to improve the physical and chemical properties of soil, as a source of liming material to ameliorate soil acidity and as a nutrient source to supply calcium and sulphur. In the construction industry, they are used mainly as a source of concrete, roofing material and road surface sealing. Increasingly, CCPs are used in the remediation of contaminated environments including control of acid mine drainage, mitigating phosphorus leaching in farm lands and immobilization of toxic metals in mine sites and agricultural soils.
\end{abstract}

Keywords: Coal, heavy metals, combustion products.

\section{INTRODUCTION}

Coal Combustion Products (CCPs) result from the combustion of coal, both in the presence and absence of bedding materials in coal-fired power stations. The volume of waste generated and problems with safe disposal make these by-products a menace to public health and environment. The rate of CCPs generation has been steadily increasing and is also predicted to ascend in the next two decades, mainly due to the intensification in coal usage for energy production (WEC, 2007). The rising Asian economies and the already developed nations like USA and Australia are projected to increase their energy needs thereby conflicting with Kyoto Protocol, although they are not part of the treaty.

Coal is derived from peat and as geological processes apply pressure to peat over time, it is transformed into the following types based on their organic maturity (WCI, 2009): 
- Lignite (brown coal) - is the lowest rank of coal and used solely as fuel for steam-electric power generation.

- Sub-bituminous coal - properties range from those of lignite to bituminous coal and are used primarily as fuel for steamelectric power generation.

- Bituminous coal - a dense coal, usually black, sometimes dark brown, used primarily as fuel in steam-electric power generation, with substantial quantities also used for heat and power applications in manufacturing and to make coke.

- Anthracite - the highest rank of coal and is a harder, glossy and black coal used primarily for residential and commercial space heating.

Coal-fired power stations generate a number of by-products during the combustion of coal. Coal is usually burnt in a pulverised fuel furnace, resulting in two major types of ash products (CCPs) the fly ash (FA) and the bottom ash (BA). The FA, which is recovered from the flue gas, has fine texture and is the major portion $(90 \%)$ of ash produced. The remainder is collected at the bottom of the furnace as BA (coarser than FA). Apart from these two ash products, two other by-products - fluidised bed combustion (FBC) ash and flue gas desulphurisation (FGD) ash are produced as part of Clean Coal technologies, mainly to trap sulphur oxides $\left(\mathrm{SO}_{\mathrm{x}}\right)$ produced during the combustion of high sulphur (S) containing coal (Stout et al., 1998).

The use of CCPs as a soil amendment has been an ongoing area of investigation in many countries that produce coal and also use coal as an energy source. Following a brief overview of the types of CCPs, volume of production and their industrial, agricultural and environmental applications, the review focuses on the role of CCPs in managing the bioavailability of nutrients such as nitrogen, phosphorus, sulphur and calcium, and heavy metals such as cadmium, lead and mercury in relation to enhancing soil chemical fertility and mitigating metal contaminated soils.

Coal reserves are available in almost every country worldwide, with recoverable reserves in around 70 countries. At current production levels, proven coal reserves are estimated to last 122 years. In contrast, proven oil and gas reserves are equivalent to around 42 and 60 years at current production levels, respectively. This forecasts the potential continuing dominance of coal in energy production in the most successful industrial nations like United States, China, India, Australia and South Africa, where the coal power plants contribute over $50 \%$ to the energy needs of these countries (Figure 1) (WCI, 2008).

Global coal consumption is expected to increase at an average rate of $1.7 \%$ per year until 2020 and share of coal in world primary energy demand will remain stable at about 25\% until 2020 (IEA, 2003). Although the coal industry welcomed the progress made in the Copenhagen summit (2009), it urged the governments to be more ambitious on climate change and work quickly to reach a legally binding agreement to replace the Kyoto Protocol as early as possible in 2010 (WCI, 2009). This will eventually drive the industrially powerful countries to invest on clean coal technologies and ensure effective carbon capture and storage. The clean coal technologies include the safe disposal and beneficial utilisation of post combustion products the CCPs. 


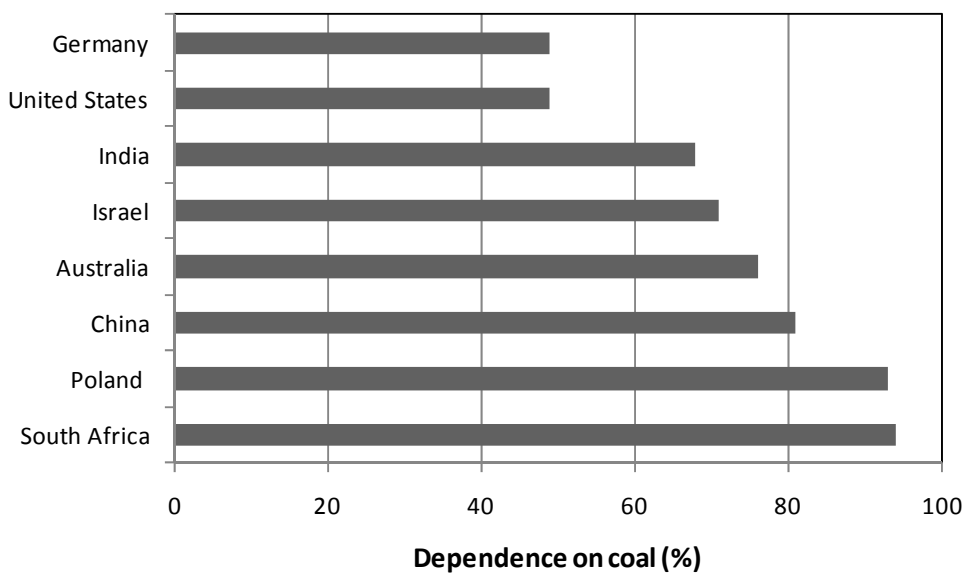

Figure 1. Countries depending on coal for their energy needs.

\section{Sources, types and basic characteristics of CCPs}

The Ash Development Association of Australia has recently updated the definitions of CCPs as follows (ADAA, 2009):

Fly ash (FA) - the non-combustible oxidized elements, light to mid-grey in colour, with sphere-shaped particles ranging in size from less than $1 \mu \mathrm{m}$ to $200 \mu \mathrm{m}$ that exit the combustion chamber in the flue gas and is captured using electrostatic precipitators, filter baghouses, or wet scrubbers (Heidrich, 2003). FA has typical pozzolanic characteristics (siliceous, or siliceous and aluminous material).

Bottom ash (BA) - agglomerated ash particles formed in pulverized coal furnaces that are too large to be carried in the flue gas stream and impinge on the furnace walls or fall through open grates to an ash hopper at the bottom of the furnace. Bottom ash is typically grey to black in colour, is quite angular, and has a porous surface structure.
Fluidised bed combustion (FBC) ash - is formed when fine coal is burnt in the presence of crushed limestone as a bedding material in fluidized form. The FBC is a technology employed to limit the amount of $\mathrm{S}$ released into the atmosphere while burning S-rich coal. Sulphur dioxide $\left(\mathrm{SO}_{2}\right)$ released during combustion is converted to calcium sulphate $\left(\mathrm{CaSO}_{4}\right)$ through its reaction with the calcined limestone. Fluidized bed furnaces burn coal at lower temperatures $\left(815-870^{\circ} \mathrm{C}\right)$ than the conventional coal fired furnaces (1400 $\left.1600^{\circ} \mathrm{C}\right)$. The chemical reactions involving the limestone charge in a fluidized bed boiler can be described by the following equations:

$$
\begin{aligned}
& \mathrm{CaCO}_{3} \rightarrow \mathrm{CaO}+\mathrm{CO}_{2} \\
& \mathrm{CaO}+\mathrm{SO}_{2} \rightarrow \mathrm{CaSO}_{3} \\
& 2 \mathrm{CaSO}_{3}+\mathrm{O}_{2} \rightarrow 2 \mathrm{CaSO}_{4}
\end{aligned}
$$

Because of its relatively low cost, the FBC technique has become widely used for reducing $\mathrm{SO}_{2}$ emissions from electricity-generating plants. Existing coal fired power plants can be modified 
to $\mathrm{FBC}$, and therefore present a simple option for bringing older plants into compliance with clean air legislation (Wang et al., 1994).

\section{Flue-gas-desulphurization}

(FGD) ash - is the residue of alkaline scrubbing of sulphur oxides from flue gases of coal-fired power stations. A range of amendments including lime and ammonia are used to trap sulphur oxides, resulting in a range of FGD products. For example, FGD gypsum is obtained in the desulphurization of flue gases with lime or limestone suspension. Similarly, ammonia FGD is produced by reacting ammonium hydroxide with $\mathrm{SO}_{2}$ to form ammonium sulphite, which is oxidized to ammonium sulphate. Apart from over $95 \% \mathrm{SO}_{2}$ removal capacity, this technology can also reduce the emission of other acid gases like sulphur trioxide and hydrogen chloride (Srivastava, 2000).

The chemistry of the production of $\left(\mathrm{NH}_{4}\right)_{2} \mathrm{SO}_{4}$ from boiler flue gas is very similar to the chemistry of wet limestone FGD. $\mathrm{SO}_{2}$ from the flue gas is absorbed in the spray tower by water according to the equation:

$$
\mathrm{SO}_{2}+\mathrm{H}_{2} \mathrm{O} \longleftrightarrow \mathrm{H}_{2} \mathrm{SO}_{3}
$$

The $\mathrm{H}_{2} \mathrm{SO}_{3}$ is then reacted in a reaction tank with ammonia to form $\left(\mathrm{NH}_{4}\right)_{2} \mathrm{SO}_{3}$ and $\mathrm{NH}_{4} \mathrm{HSO}_{3}$ :

$$
\begin{aligned}
& \mathrm{H}_{2} \mathrm{SO}_{3}+2 \mathrm{NH}_{3} \longleftrightarrow\left(\mathrm{NH}_{4}\right)_{2} \mathrm{SO}_{3} \\
& \mathrm{H}_{2} \mathrm{SO}_{3}+\left(\mathrm{NH}_{4}\right)_{2} \mathrm{SO}_{3} \longleftrightarrow 2 \mathrm{NH}_{4} \mathrm{HSO}_{3}
\end{aligned}
$$

$\left(\mathrm{NH}_{4}\right)_{2} \mathrm{SO}_{3}$ and $\mathrm{NH}_{4} \mathrm{HSO}_{3}$ are also oxidized in the absorber (forced oxidation) to form $\left(\mathrm{NH}_{4}\right)_{2} \mathrm{SO}_{4}$ and $\mathrm{NH}_{4} \mathrm{HSO}_{4}$. The $\mathrm{NH}_{4} \mathrm{HSO}_{4}$ is neutralised in the presence of ammonia and water to form $\left(\mathrm{NH}_{4}\right)_{2} \mathrm{SO}_{4}$ :

$$
\begin{gathered}
\mathrm{NH}_{4} \mathrm{HSO}_{4}+\mathrm{NH}_{3}+\mathrm{H}_{2} \mathrm{O} \\
\left(\mathrm{NH}_{4}\right)_{2} \mathrm{SO}_{4}+\mathrm{H}_{2}
\end{gathered}
$$

The fuel and S-capturing sources dictate the composition of these by-products in the coal industry. For example, the FBC ash is highly alkaline because of the presence of unspent sorbent, and also contains anhydrite, thus has potential to be used as liming material and $\mathrm{S}$ fertilizer; whereas FGD gypsum is nearly neutral and primarily used as a source of S.

In supplying the power requirements for Australian households, around 14.6 Mt (million tonnes) of CCPs are produced annually of which about only $1.787 \mathrm{Mt}$ is utilized primarily in the construction industry. In Australasia, about $85 \%$ of the current "beneficial use" of fly ash is for partial cement replacement (between $10 \& 20 \%$ ) to enhance the properties of concrete and other building materials. Only about 0.5 Mt $(3 \%)$ is used for non-cementitious applications, which include agriculture and environment (ADAA, 2008). Similarly, ash utilization as a percentage of total ash generated in different countries amounts to around $85 \%$ in West Germany, 73\% in Denmark, 60\% in France and UK, 50\% in Poland, 32\% in US, $25 \%$ in China and $15 \%$ in India (Sinha and Basu, 1998). However, there is a high potential for greater utilisation of these CCPs in Australia and worldwide.

\section{Properties of coal combustion products}

The physical and chemical properties of CCPs depend upon a number of factors, including the origin and the type of coal burnt, boiler conditions, type and efficiency of the emission controls and nature of sorbents used to trap $\mathrm{S}$ (Adriano et al., 1980; Stout et al., 1998; Wang et al., 2006), but certain characteristics tend to be similar in most ashes. Chemically, CCPs are mainly 
silico-aluminate glasses, though some mineral materials may also be present. Based on the chemical composition, FA is grouped into two classes $-\mathrm{F}$ and $\mathrm{C}$ (ASTM, 1994). They primarily differ in the amount of calcium and the silica, alumina, and iron content in the ash, which also vary among the types of coal used (Table 1). Class F FA is highly pozzolanic and has total calcium content typically ranging from 1 to $12 \%$, mostly in the form of calcium hydroxide and calcium sulphate. In contrast, Class C FA contains calcium content as high as 30 to $40 \%$. Another difference between Class $\mathrm{F}$ and Class $\mathrm{C}$ is that the amount of alkalis (combined sodium and potassium) and sulphates $\left(\mathrm{SO}_{4}\right)$ are generally higher in the Class $\mathrm{C}$ fly ashes than in the Class $\mathrm{F}$ fly ashes. Countries like United States and India, which produces Class C fly ashes, need to strictly implement clean coal technologies like FBC and FGD for this reason. In Australia, the majority of ash produced is categorised as Class F being mainly silica and alumina (80$85 \%$ ) and less than $10 \% \mathrm{CaO}$ (Table 1 ).

Table 1. Normal range of chemical composition for fly ash produced from different coal types (expressed as percentage by weight). ASTM (1994).

\begin{tabular}{cccc}
\hline Component & Bituminous & $\begin{array}{c}\text { Sub- } \\
\text { bituminous }\end{array}$ & Lignite \\
\hline $\mathrm{SiO}_{2}$ & $20-60$ & $40-60$ & $15-45$ \\
$\mathrm{Al}_{2} \mathrm{O}_{3}$ & $5-35$ & $20-30$ & $10-25$ \\
$\mathrm{Fe}_{2} \mathrm{O}_{3}$ & $10-40$ & $4-10$ & $4-15$ \\
$\mathrm{CaO}$ & $1-12$ & $5-30$ & $15-40$ \\
$\mathrm{MgO}$ & $0-5$ & $1-6$ & $3-10$ \\
$\mathrm{SO}_{3}$ & $0-4$ & $0-2$ & $0-10$ \\
\hline
\end{tabular}

Generally, the CCPs are mainly composed of silt-sized materials having a diameter from $0.01-100 \mu \mathrm{m}$ (Kula et al., 2002; Peng et al., 2004). When compared with mineral soils, FA has lower values for bulk density, hydraulic conductivity and specific gravity. Both crystalline (mullite) and amorphous (glass) phases have been identified by Xray diffraction in fly ash (Mattigod et al., 1990; Karayigit and Gayer, 2001).

The chemical properties of CCPs will largely be determined by the metal oxides ( $\mathrm{Si}, \mathrm{Al}, \mathrm{Fe}, \mathrm{Ca}, \mathrm{Mg}, \mathrm{Na}, \mathrm{K}$ ) that are surface adsorbed during particle formation (Terman et al., 1978; Adriano et al., 1980). Most of these elements can substitute into the iron pyrite structure, and coals higher in pyrite therefore tend to produce CCPs which contain higher levels of these elements. The behavior of volatile elements such as $\mathrm{Se}$ and $\mathrm{Hg}$ is highly dependent upon the burning conditions within the boiler and the sorbents used for capturing S (Punshon et al., 2003). During the combustion and subsequent cooling process many different metal oxides can precipitate and concentrate on the surfaces of fly ash particles. Based on reactivity and surface electric charge, three groups of solid components have been identified in fly ash (Terman et al., 1978; Adriano et al., 1980; Table 2).

Table 2. Groups of solid components in fly ash (Adriano et al., 1980).

\begin{tabular}{|c|c|c|}
\hline Groups & Properties & Components \\
\hline Group I & $\begin{array}{c}\text { Low water } \\
\text { reactivity, } \\
\text { possess surface } \\
\text { charge }\end{array}$ & $\begin{array}{c}\text { Oxides of } \mathrm{Si}, \mathrm{Al}, \\
\mathrm{Fe} \text { and } \mathrm{Ti}\end{array}$ \\
\hline Group II & $\begin{array}{l}\text { Adsorption to } \\
\text { oxides }\end{array}$ & $\begin{array}{l}\text { Metals and } \\
\text { metalloids }\end{array}$ \\
\hline Group III & $\begin{array}{l}\text { High water } \\
\text { reactivity }\end{array}$ & $\begin{array}{c}\text { Oxides of } \mathrm{Ca}, \mathrm{Mg}, \\
\mathrm{K}, \mathrm{Na}, \mathrm{Ba}, \mathrm{SO}_{3}, \\
\text { Gypsum }\end{array}$ \\
\hline
\end{tabular}

The above mentioned physical and chemical properties of CCPs have driven coal industries and environment 
researchers to explore the possible applications as part of the sustainable utilization strategies of these mine derived resources.

\section{Application of coal combustion products}

Currently, CCPs are used extensively in construction and agricultural industries. In the construction industry, they are used mainly as a source of concrete, roofing material and road surface sealing (Chugh et al., 2006). The various types of CCPs and their potential applications are listed in the Table 3. In agricultural industries, they are used primarily as an amendment to improve the physical and chemical properties of soil, as a source of liming material to ameliorate soil acidity and as a nutrient source to supply calcium and sulphur (Heidrich, 2003; Wang et al., 2006).

About $85 \%$ of the current use of FA is for partial cement replacement (10-20\%) to enhance the properties of concrete and other building materials. The BA is used as a sand replacement, aggregate for lightweight blocks, a road-base component, for agricultural drainage mediums and as an engineered bulk fill. The pozzolanic property of FA means in finely divided form and in the presence of moisture, it could chemically react with calcium hydroxide at ordinary temperatures to form compounds that have cementitious properties. As a partial replacement of the sand and cement in concrete, FA economically enhances performance in regard to workability, shrinkage creep and durability to produce high-performance concrete (Kurita and Nomura, 1998; Bilodeau and Malhotra, 2000).

The idea of utilizing CCPs in agriculture has originally arisen as a result of their role as a nutrient supplement in soils low in $\mathrm{Se}, \mathrm{Mo}, \mathrm{Cu}$,
Zn, or B (Page et al., 1979; Adriano et al., 1980; Kesh et al., 2003; Yunusa et al., 2006). The CCPs in general and FA in particular have a considerable content of K, Ca, Mg, S and P (Page et al., 1979; Adriano et al., 1980; Singh et al., 1997; Yunusa et al., 2006), which help in increasing plant growth and nutrient uptake.

Much research and development has been carried out in the past three decades on the use of fly ash in agriculture (Page et al., 1979; Stehouwer et al. 1996; Stout et al. 2003; Wang et al., 2006), where the potential of CCPs as liming agent, source of plant nutrients, and soil modifier has been exploited. The uptake or enrichment of various nutrients and toxic trace elements (Table 4) in soil after CCPs amendments has been investigated, and crop produce has been found safe for consumption (Sen et al., 1997).

The agricultural use of CCPs highly depends on the nature of parent coal used and coal combustion technologies used for power generation (El Mogazi et al., 1988; Wang et al. 1994). The agricultural use of CCPs has often been assessed in relation to its effects on: (1) crop yield and establishment; (2) uptake and accumulation of nutrient and nonnutrient elements; and (3) toxicity levels of trace elements (Table 4).

The CCPs are also used for various environmental applications that include: (a) Phosphorus retention; (b) Heavy metal immobilisation; (c) Acid mine drainage (AMD) mitigation and mine site reclamation; and (d) Carbon sequestration. For example, Stehouwer et al. (1995) demonstrated the value of CCPs as an amendment for coal refuse piles and non-agricultural lands, especially for reclaiming mined areas. Similarly, Gitari et al. (2006) examined the value of CCPs in mitigating AMD. 
Table 3. Various types of CCPs - their major constituents and potential uses.

\begin{tabular}{|c|c|c|}
\hline Type & Major constituents & Potential areas of major use \\
\hline Fly ash & $\begin{array}{l}\mathrm{Si}, \mathrm{Al}, \mathrm{Fe}, \mathrm{Ca}(\mathrm{CaO} \\
\mathrm{MgO}, \mathrm{SiO}_{2}, \mathrm{~K}_{2} \mathrm{O} \\
\left.\quad \mathrm{Al}_{2} \mathrm{O}_{3}, \mathrm{Fe}_{2} \mathrm{O}_{3}\right)\end{array}$ & $\begin{array}{l}\text { Cement replacement in concrete/grout, structural fill, } \\
\text { flowable fill, waste stabilization, surface mine } \\
\text { reclamation, soil stabilization, road based, mineral } \\
\text { filler, Si and Ca source }\end{array}$ \\
\hline Boiler slag & $\begin{array}{l}\mathrm{Si}, \mathrm{Al}, \mathrm{Fe}, \mathrm{Ca}(\mathrm{CaO} \\
\mathrm{MgO}, \mathrm{SiO}_{2}, \mathrm{~K}_{2} \mathrm{O} \\
\left.\quad \mathrm{Al}_{2} \mathrm{O}_{3}, \mathrm{Fe}_{2} \mathrm{O}_{3}\right)\end{array}$ & $\begin{array}{l}\text { Blasting grit, roofing granules, snow and ice control, } \\
\text { mineral filler, construction backfill, water filtration, } \\
\text { drainage media }\end{array}$ \\
\hline $\begin{array}{l}\text { Bottom } \\
\text { ash }\end{array}$ & $\begin{array}{c}\mathrm{Si}, \mathrm{Al}, \mathrm{Fe}, \mathrm{Ca}, \mathrm{S} \\
\left(\mathrm{CaSO}_{4}, \mathrm{CaO}, \mathrm{CaSO}_{3},\right. \\
\mathrm{MgO}, \mathrm{SiO}_{2}, \mathrm{~K}_{2} \mathrm{O} \\
\left.\mathrm{Al}_{2} \mathrm{O}_{3}, \mathrm{Fe}_{2} \mathrm{O}_{3}\right)\end{array}$ & $\begin{array}{l}\text { Concrete block, road sub-base, snow and ice control, } \\
\text { structural fill, waste stabilization, pipe bedding, } \\
\text { cement manufacture, liming material, Si, Ca and S } \\
\text { source }\end{array}$ \\
\hline $\begin{array}{l}\text { FGD } \\
\text { material }\end{array}$ & 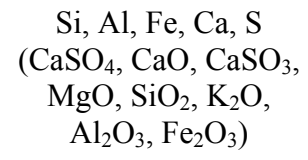 & $\begin{array}{l}\text { Wallboard, stabilised road base/sub-base, structural } \\
\text { fill, surface mine reclamation, underground mine } \\
\text { injection, livestock pad, low permeability liner, } \\
\text { synthetic aggregate, sludge stabilization }\end{array}$ \\
\hline $\begin{array}{l}\text { FBC } \\
\text { material }\end{array}$ & $\begin{array}{l}\mathrm{Si}, \mathrm{Al}, \mathrm{Fe}, \mathrm{Ca}, \mathrm{S} \\
\left(\mathrm{CaSO}_{4}, \mathrm{CaO}, \text { Quartz, }\right. \\
\text { gypsum })\end{array}$ & Slow release fertiliser, liming material \\
\hline
\end{tabular}

\section{Bioavailability of nutrients and heavy metals}

Application of CCPs to soil influences the bioavailability of nutrients and heavy metals by acting as a source and also by affecting their transformation in soils (Table 5). For example, depending on the origin, CCPs contain appreciable amounts of nutrients such as sulphur, calcium and magnesium and heavy metals such as cadmium, chromium and mercury, thereby acting as a source of these elements (Table 4). Similarly, the application of CCPs is likely to affect soil properties such as $\mathrm{pH}$ and cation exchange capacity, thereby influencing the reaction and transformation of nutrients and heavy metals.
Bioavailability refers to how much of a chemical is available to a living biota including plants and soil microorganisms. (Naidu et al., 2008) However, the bioavailability of a chemical defines the relationship between the concentration of the chemical in the terrestrial environment and the level of the chemical that actually enters the receptor causing either positive or negative effect on the organism. Bioavailability is species-specific because the dose which reaches an organism's target organs or tissues, and results in a biological response, may vary among receptors (Stokes et al., 2005). Bioavailability is also often referred to as the extent to which a chemical can desorb, dissolve, or otherwise dissociate from the environmental medium in which it occurs 
to become accessible (i.e bioaccessibility) for absorption (Alexander and Alexander, 2000). Chemical bioavailability is now considered an important issue in the environment because the availability of chemicals may be mitigated once the chemical comes in contact with the soil and sediment. For this reason, both fertility status of soils and risk assessment of contaminated sites require quantification of chemical bioavailability much like any other parameter in fertilizer recommendation and risk calculations (Hrudey et al., 1996). In both fertilizer recommendation and contaminated site assessment, bioavailability addresses the fundamental issue of exposure of the element to a receptor. However, exposure is not dictated by the total concentration of the element in the environmental media, but rather by the fraction of the total concentration of the element that is biologically available. Hence, exposure can only occur following the release (e.g. desorption) of the element from the soil particle and if the element is then transported to the receptor. The amount of an element in soil that is bioavailable depends on a variety of factors including the properties of both the element and the soil environment (Adriano et al., 2004).

\section{Nutrients}

Numerous studies have examined the value of CCPs as a nutrient source (Table 4). The major nutrient elements in CCPs include $\mathrm{Si}, \mathrm{Al}, \mathrm{Fe}, \mathrm{Ca}$ and $\mathrm{S}$, together with lesser amounts of $\mathrm{Na}, \mathrm{Mg}$, $\mathrm{B}, \mathrm{Sr}$ and $\mathrm{K}$. For example, FBC and FGD ashes have $\mathrm{Ca}$ and $\mathrm{Mg}$ contents ranging from $13 \%$ to $39 \%$ and from $0.1 \%$ to $16 \%$, respectively depending on whether the sorbent is calcite or dolomite. Due to the presence of unspent sorbent, FBC ash is usually highly alkaline $\quad\left(\mathrm{pH}_{\text {water }} 10.5-12.5\right)$ with significant neutralization potential. It has been reported that the best agricultural use of FBC ash is as a liming source to overcome the problems associated with soil acidity (Terman et al., 1978; Stout and Priddy, 1996; Wang et al. 1994). The S content of FBC and FGD ashes is also relatively high, being mainly in the form of $\mathrm{CaSO}_{4}$ (anhydrite). Therefore, these two are a major source of both $\mathrm{Ca}$ and $\mathrm{S}$ for plant nutrition in addition to relatively high liming value (Wang et al. 1994). Compared with $\mathrm{Ca}$ and $\mathrm{S}$, the amounts of $\mathrm{N}, \mathrm{P}$ and $\mathrm{K}$ in CCPs are negligible. The micronutrient content in CCPs is low except for boron (B) that ranges from 36 to $1360 \mathrm{mg} \mathrm{kg}^{-1}$ (Table 4). Boron is an essential mineral nutrient for all vascular plants. The functions of B are primarily extracellular, which relates to lignification and xylem differentiation. Some of the CCPs such as FBC ash also contain small amounts of selenium (Se, 0.16 - $5.6 \mathrm{mg} \mathrm{kg}{ }^{-1}$ ) which is an essential nutrient for animals but not for plants. Due to the oxidizing conditions to which these elements are exposed during combustion, $\mathrm{Fe}, \mathrm{Mn}, \mathrm{Cu}$ and $\mathrm{Zn}$ probably occur as oxides in FBC ash, and B and Mo as borates and molybdates (Table 5).

The presence of $\mathrm{S}$ in FBC and FGD ashes as anhydrite $\left(\mathrm{CaSO}_{4}\right)$ or gypsum $\left(\mathrm{CaSO}_{4} \cdot 2 \mathrm{H}_{2} \mathrm{O}\right)$ after hydration makes these CCPs the major $\mathrm{S}$ source in Sdeficient soils. Gypsum, including industrial by-products, such as phosphogypsum, has been successfully used as an $\mathrm{S}$ fertilizer to increase the yields of winter wheat, rice and pasture. To date, data on the use of these two CCPs as a $\mathrm{S}$ fertilizer is limited, although Terman et al. (1978) demonstrated that FBC ash is an effective $\mathrm{S}$ source for growing corn and peanuts. Approximately $50 \%$ of $\mathrm{S}$ in slaked FBC ash is present as sparingly soluble ettringite, which can act as a slowrelease $\mathrm{S}$ fertilizer (Wang, 1996). 
Table 4. Selected references on nutrient and heavy metal concentrations in CCPs

\begin{tabular}{|c|c|c|c|c|c|c|c|c|c|c|c|c|c|c|c|}
\hline \multirow[t]{2}{*}{ CCPs } & \multicolumn{8}{|c|}{ Nutrients $\left(\mathrm{g} \mathrm{kg}^{-1}\right)$} & \multicolumn{6}{|c|}{ Trace elements $\left(\mathrm{mg} \mathrm{kg}^{-1}\right)$} & \multirow[t]{2}{*}{ Ref.* } \\
\hline & $\mathbf{P}$ & $\mathbf{S}$ & Al & $\mathbf{C a}$ & $\mathbf{F e}$ & Mg & $\mathbf{N a}$ & B & As & Cd & $\mathrm{Cr}$ & Hg & $\mathbf{P b}$ & Se & \\
\hline \multirow{6}{*}{$\begin{array}{l}\text { Fly } \\
\text { ash }\end{array}$} & - & - & - & - & - & - & - & 1.69 & 7.0 & 0.1 & 38 & 1.3 & 15 & 2.9 & 1 \\
\hline & $\begin{array}{c}0.956- \\
1.002\end{array}$ & - & $\begin{array}{l}110- \\
130\end{array}$ & $\begin{array}{l}5.3- \\
5.7\end{array}$ & $\begin{array}{l}82- \\
100\end{array}$ & $\begin{array}{c}4.977- \\
5.494\end{array}$ & $\begin{array}{c}2.322- \\
2.553\end{array}$ & $\begin{array}{l}0.003- \\
0.0036\end{array}$ & $\begin{array}{l}116- \\
129\end{array}$ & $\begin{array}{c}2.8- \\
3.5\end{array}$ & $\begin{array}{l}155- \\
169\end{array}$ & $\begin{array}{c}0.27- \\
0.45\end{array}$ & $60-63$ & $12-17$ & 2 \\
\hline & $\begin{array}{l}1.388- \\
1.432\end{array}$ & $\begin{array}{c}1.26- \\
1.3\end{array}$ & $\begin{array}{l}75- \\
117\end{array}$ & $13-14$ & $41-73$ & $\begin{array}{l}5.179- \\
5.426\end{array}$ & $\begin{array}{c}4.183- \\
4.420\end{array}$ & $\begin{array}{c}0.0199 \\
- \\
0.0211\end{array}$ & $\begin{array}{l}112- \\
125\end{array}$ & $\begin{array}{l}3.0- \\
5.0\end{array}$ & $\begin{array}{l}97- \\
155\end{array}$ & $\begin{array}{c}0.22- \\
0.31\end{array}$ & $\begin{array}{l}247- \\
263\end{array}$ & $8.4-11$ & 3 \\
\hline & $0.4-8$ & $1-15$ & $1-173$ & $\begin{array}{l}1.1- \\
222\end{array}$ & $\begin{array}{l}10- \\
290\end{array}$ & $0.4-76$ & $\begin{array}{l}0.1- \\
20.3\end{array}$ & $\begin{array}{c}0.01- \\
6.18\end{array}$ & $\begin{array}{c}2.3- \\
6300\end{array}$ & $\begin{array}{l}0.7- \\
130\end{array}$ & $\begin{array}{c}10- \\
1000\end{array}$ & $\begin{array}{c}0.02- \\
1.0\end{array}$ & $\begin{array}{c}3.1- \\
5000\end{array}$ & $\begin{array}{l}0.2- \\
134\end{array}$ & 4 \\
\hline & 0.2315 & 2.738 & 4.136 & 8.435 & 13.51 & 4.66 & 0.37 & 0.298 & - & 2.8 & 26.8 & - & 2.5 & - & 5 \\
\hline & 3.760 & 0.948 & 147 & 27.4 & 90.9 & 8.87 & 2.39 & 0.056 & 22.3 & 0.52 & 69.2 & - & 49 & 2.26 & 6 \\
\hline \multirow[t]{4}{*}{ FBA } & - & - & 13.0 & 300 & 55.0 & 18.0 & 1.0 & - & - & $<2$ & 50.0 & - & 85.0 & - & 7 \\
\hline & 0.875 & 62.0 & 18.0 & 254 & 36.0 & 6.0 & 7.0 & 1.36 & 6.5 & $<0.1$ & $<0.1$ & - & $<2.0$ & $<3.0$ & 8 \\
\hline & 0.1 & 86.4 & 27.5 & 244 & 20.8 & 163 & 9.5 & 0.206 & 46.7 & 3.5 & 17.5 & - & 28.0 & 2.3 & 9 \\
\hline & 0.2 & 38 & 0.1 & 391 & 5.0 & 5.0 & - & 1.328 & 8.1 & 0.2 & 33 & - & 88.0 & 3.3 & 10 \\
\hline \multirow[t]{4}{*}{ FGD } & 0.573 & 85 & 25.5 & 146 & 85 & 3.7 & 0.722 & 0.356 & 107 & $<0.2$ & 51 & - & 15 & - & 11 \\
\hline & - & 67.1 & 19.6 & 260 & 16.5 & 27.1 & - & 0.194 & 118 & $<0.1$ & 123 & - & 139 & $<6.0$ & 12 \\
\hline & 0.2 & 182 & 8.0 & 201 & 0.1 & 0.4 & - & 0.131 & 6.3 & 0.7 & 15.0 & - & 100 & 2.3 & 13 \\
\hline & - & 205.4 & 3.3 & 269.1 & - & 4.5 & - & - & 1.08 & $<0.1$ & 9.70 & 0.658 & 4.08 & 0.84 & 14 \\
\hline
\end{tabular}

*References: (1) McDowell (2005); (2) Punshon et al. (2002); (3) Adriano et al. (2002); (4) Sharma and Kalra (2006); (5) Sajwan et al. (2007); (6) J.Jankowski et al. (2006); (7) Karapanagioti and Atalay (2001); (8) Wang et al. (1994); (9) Stehouwer et al. (1996); (10) Wright et al. (1998); (11) Ahn and Mitsch (2001); (12) Chen et al. (1995); (13) Wright et al. (1998); (14) Wang et al. (2008). 
J. Soil Sci. Plant Nutr. 10(3): 378 - 398 (2010

Table 5. Selected references on CCP-induced mobilization of nutrients and heavy metals in soils.

\begin{tabular}{|c|c|c|c|}
\hline Nutrients & CCP source & Observations & Reference \\
\hline \multicolumn{4}{|c|}{ Nutrients } \\
\hline \multirow[t]{9}{*}{ Nitrogen } & FA and BA & $\begin{array}{l}\text { Although applications of CCPs had little influence on fertilizer } \mathrm{N} \text {, application of BA caused } \\
\text { substantial decreases in the total } \mathrm{N} \text { content in soil solution through the mobilization of organic } \mathrm{N} \\
\text { and } \mathrm{N} \text { losses in the forms of amino sugars, amino acids, and hydrolysable } \mathrm{NH}_{4}^{+} \text {could account } \\
\text { largely for losses of total } \mathrm{N} \text { in BA-amended soils, resulting an increase in soil } \mathrm{pH} .\end{array}$ & Stuczynski et al. (1998) \\
\hline & FA & FA is low in N; co-composting FA with biosolid increases the supply of N & Alva et al. (1999) \\
\hline & FA & $\begin{array}{l}\text { FA is low in nitrogen but increased the mineralization of organic N. Organic matter rich soils or N- } \\
\text { fixing plants with an apparent heavy metal-tolerance can be helpful as the early colonisers of FA } \\
\text { dumps and nearby areas. }\end{array}$ & Gupta et al. (2002) \\
\hline & FA & $\begin{array}{l}\text { Gypsum-FA mixture application }\left(25 \text { tons ha } \mathrm{h}^{-1}\right) \text { increased the maximum rice grain yield by } 8 \% \text {, } \\
\text { thereby decreasing } \mathrm{N} \text { application level to about } 50 \mathrm{~kg} \mathrm{~N} \mathrm{ha}^{-1} \text { to produce the target yield. }\end{array}$ & Lee et al. (2003) \\
\hline & FA & Enhanced $\mathrm{N}$ release from cow dung when vermicomposted in the presence of FA. & $\begin{array}{l}\text { Battacharya and } \\
\text { Chattopadhyay (2004) }\end{array}$ \\
\hline & FA & $\begin{array}{l}\text { FA is an important source of alkalinity in the upper } 0 \text { to } 5 \mathrm{~cm} \text { of lignite containing lake sediments } \\
\text { that enhanced plant growth and led to enrichment of the sediment with } \mathrm{N} \text { from organic matter } \\
\text { derived from plant material }\end{array}$ & Chabbi and Rumpel (2004) \\
\hline & FA & $\begin{array}{l}\text { Integrated use of FA, bluegreen biological fertilizer and } \mathrm{N} \text { fertilizer improved growth, yield and } \\
\text { mineral composition of the rice plants besides reducing the high demand of } \mathrm{N} \text { fertilizers. }\end{array}$ & Tripathi et al. (2008) \\
\hline & FA & $\begin{array}{l}\text { Addition of FA to alkaline treated wastewater sludge decreased the rate of mineralization of } \\
\text { organic } \mathrm{N} \text { in the sludge, thereby increased the residual value of sludge as a } \mathrm{N} \text { source }\end{array}$ & Topac et al. (2008) \\
\hline & FGD gypsum & $\begin{array}{l}\text { Application of FGD gypsum with } \mathrm{N} \text { fertilizer promotes the uptake of } \mathrm{N} \text { by corn in S-responsive } \\
\text { soils, thereby decreasing the amount of } \mathrm{N} \text { required for high-yield corn production and reducing the } \\
\text { degradation of water quality associated with oversupply of } \mathrm{N}\end{array}$ & Chen et al. (2008) \\
\hline
\end{tabular}


Continued.....

\begin{tabular}{|c|c|c|c|}
\hline Nutrients & CCP source & Observations & Reference \\
\hline \multirow[t]{12}{*}{ Phosphorus } & FA and BA & $\begin{array}{l}\text { While alkaline FA had higher sorption maxima, BA and acidic FA had very low sorption capacity } \\
\text { at low concentrations. Results suggested that alkaline FA may be a promising amendment for } \\
\text { coarse sand bed to enhance P removal. }\end{array}$ & Cheung et al. (1994) \\
\hline & FA & $\begin{array}{l}\text { P mobilisation enhanced by organic acids and microbial activity in swine manure amended with } \\
\text { fly ash; B was highly soluble at the highest application rate and was detrimental to plant growth }\end{array}$ & Vincini et al. (1994) \\
\hline & FA & $\begin{array}{l}\text { Immediate and long-term decreases in P desorption occurred in the incubation study at all ash rates } \\
\text { when greater than } 500 \mathrm{mg} \mathrm{P} \mathrm{kg}^{-1} \text { were added but FA had little effect on P desorption at P rates less } \\
\text { than } 50 \mathrm{mg} \mathrm{P} \mathrm{kg}^{-1}\end{array}$ & O'Reilly and Sims (1995) \\
\hline & FA & $\begin{array}{l}\text { Coapplications of FA and animal manure products stabilized manure } \mathrm{P} \text {, thereby allowing land } \\
\text { application rates needed to fulfil plant } \mathrm{N} \text { requirements without causing water quality impairments. }\end{array}$ & Dao (1999) \\
\hline & FA & $\begin{array}{l}\text { The FA amendment retarded } \mathrm{NO}_{3}{ }^{-}, \mathrm{NH}_{4}{ }^{+} \text {, and } \mathrm{P} \text { leaching in sandy soils and can be a useful tool for } \\
\text { improvement of nutrient management in sandy soils. }\end{array}$ & Pathan et al. (2003) \\
\hline & FGD gypsum & $\begin{array}{l}\text { Treatment of high P soils with FGD gypsum decreases water-extractable } \mathrm{P} \text { by conversion to soil IP } \\
\text { fractions that are stable with time, it does not decrease plant production and suggests that the } \\
\text { potential for P export in surface runoff may be reduced for several years. }\end{array}$ & Stout et al. (2003) \\
\hline & FBC & $\begin{array}{l}\text { Increased } \mathrm{P} \text { loss }- \text { solubilisation of organic } \mathrm{P} \text { due to an increase in soil } \mathrm{pH} \text { resulting from free } \mathrm{CaO} \\
\text { content }\end{array}$ & McDowell (2004) \\
\hline & $\begin{array}{l}\text { Furnace slag } \\
\text { and FA }\end{array}$ & $\begin{array}{l}\text { The expected lifetime of constructed wetlands for P removal is likely to be increased with the use } \\
\text { of furnace slag and FA }\end{array}$ & Xu et al. (2006) \\
\hline & FA & $\begin{array}{l}\text { Application of FA to rice cultivation increased available P resulting from high content of P ( } 786 \\
\mathrm{mg} \mathrm{P} \mathrm{kg}^{-1} \text { ) in the applied FA }\end{array}$ & Lee et al. (2007a) \\
\hline & $\begin{array}{l}\text { FA plus } \\
\text { phosphogyp- } \\
\text { sum }\end{array}$ & $\begin{array}{l}\text { The mixture significantly reduced water-soluble } \mathrm{P}(\mathrm{W}-\mathrm{P}) \text { in the surface soils by shifting from W-P } \\
\text { to iron bound-P (Fe-P), calcium bound-P (Ca-P) and aluminium bound-P (Al-P) during rice } \\
\text { cultivation, thereby reducing P loss from paddy soils. }\end{array}$ & Lee et al. (2007b) \\
\hline & FA & Addition of FA to pasture soil increased the mineralization of organic $\mathrm{P}$ & McDowell et al. (2008) \\
\hline & FA & Sand amended with FA as filter media in bioretention cells increased $\mathrm{P}$ removal & Zhang et al. (2008) \\
\hline
\end{tabular}


Continued....

\begin{tabular}{|c|c|c|c|}
\hline Nutrients & CCP source & Observations & Reference \\
\hline \multirow{6}{*}{$\begin{array}{l}\text { Sulphur, } \\
\text { Calcium, } \\
\text { Potassium, } \\
\text { Magnesium } \\
\text { and Sodium }\end{array}$} & FA & Released $\mathrm{Mg}$ at rates comparable to most $\mathrm{Mg}$ fertilisers & Hill and Lamp (1980) \\
\hline & FBA & $\begin{array}{l}\text { Water soluble } \mathrm{S} \text { is up to } 50 \% \text { with slow dissolution of remaining } \mathrm{S} \text {; most of } \mathrm{K} \text { is in the soluble } \\
\text { form; dissolution of gypsum and portlandite in FBA increased soluble Ca concentration, less than } \\
50 \% \text { of the Na salts in FBA were water-extractable }\end{array}$ & Wang et al. (1994) \\
\hline & FBC & Leachate $\mathrm{Mg}$ and $\mathrm{S}$ concentrations increased as $\mathrm{MgSO}_{4}$ ion pair & Stehouwer et al. (1995) \\
\hline & FGD & $\begin{array}{l}\text { Mobility of } \mathrm{Ca}, \mathrm{Mg} \text { and } \mathrm{S} \text { increased with increasing depths of FGD application in soil. } 90 \% \text { of } \\
\text { leachate } \mathrm{S} \text { was present as } \mathrm{SO}_{4}-\mathrm{S}\end{array}$ & Stehouwer et al. (1996) \\
\hline & FA & $\begin{array}{l}\text { Soluble } \mathrm{Ca} \text { increased gradually over time under field conditions and increased sharply under } \\
\text { alternate wet-dry conditions in a lignite mine spoil }\end{array}$ & Seoane and Leiros (2001) \\
\hline & FA & Boron is highly leachable (17-64\%) from alkaline FA with, but not completely $\mathrm{pH}$ dependent & Jankowski et al. (2006) \\
\hline \multicolumn{4}{|l|}{ Heavy metals } \\
\hline $\begin{array}{l}\text { Zinc, Iron } \\
\text { and } \\
\text { Manganese }\end{array}$ & FA & $\begin{array}{l}\text { Bacterial activity in FA amended soil increased mobility of } \mathrm{Zn}, \mathrm{Fe} \text { and } \mathrm{Mn} \text { initially, but slowly } \\
\text { decreased as the incubation period increased }\end{array}$ & Tiwari et al. (2008) \\
\hline $\begin{array}{l}\text { Cadmium } \\
\text { and } \\
\text { Antimony }\end{array}$ & FA & Increased the water extractable fractions of $\mathrm{Cd}$ and $\mathrm{As}$ & $\begin{array}{l}\text { Fernández-Turiel et al. } \\
\text { (1994) }\end{array}$ \\
\hline $\begin{array}{l}\text { Aluminium, } \\
\text { Chromium } \\
\text { and } \\
\text { Vanadium }\end{array}$ & FA & Increased the water soluble bioavailable fractions of $\mathrm{Al}, \mathrm{Cr}$ and $\mathrm{V}$ & Gomez et al. (2007) \\
\hline $\begin{array}{l}\text { Copper and } \\
\text { Zinc }\end{array}$ & FA & Sequential fractionation indicated $2.6 \%$ of $\mathrm{Cu}$ and $3.4 \%$ of $\mathrm{Zn}$ in FA was water soluble. & $\begin{array}{l}\text { Soco and Kalembkiewicz } \\
\text { (2007a) }\end{array}$ \\
\hline
\end{tabular}


Continued....

\begin{tabular}{|c|c|c|c|}
\hline Nutrients & CCP source & Observations & Reference \\
\hline \multicolumn{4}{|l|}{ Heavy metals } \\
\hline Antimony & FA & $22-36 \%$ of readily soluble $\mathrm{Sb}$ in FA amended soil at acidic $\mathrm{pH}$ & Miravet et al. (2006) \\
\hline Nickel & FA & $\begin{array}{l}\text { Biological dissolution (Microbial redox actions or mammalian phagocytosis) influences } \mathrm{Ni} \\
\text { mobility in FA amended soils }\end{array}$ & Wong et al. (1997) \\
\hline Chromium & FA & $\begin{array}{l}\text { Under extreme environmental conditions (oxidizable or reducible) FA increases } \mathrm{Cr} \text { mobility from } \\
8.2 \% \text { to } 52.4 \% \mathrm{Cr} \text {. }\end{array}$ & $\begin{array}{l}\text { Soco and Kalembkiewicz } \\
(2007 \mathrm{~b})\end{array}$ \\
\hline Arsenic & FA & Phosphate in FA displaced As, thereby increasing its mobility & Qafoku et al. (1999) \\
\hline $\begin{array}{l}\text { Molybdenum } \\
\text { and Selenium }\end{array}$ & FA & Increased Mo and Se availability in soil at elevated $\mathrm{pH}$ & $\begin{array}{l}\text { Carlson and Adriano } \\
\text { (1993) }\end{array}$ \\
\hline
\end{tabular}


Therefore, slaked FBC ash shows potential to be used as a basal $\mathrm{S}$ fertilizer in soils prone to severe leaching, which are common in some high rainfall areas of New Zealand and in soils with low anion retention capacities. For example, results from a field study in the peat soil indicated that ettringite- $\mathrm{S}$ in slaked FBC ash was less affected by leaching loss than gypsum and resulted in longer-term pasture yield $\mathrm{S}$ responses to $\mathrm{FBC}$ ash treatments (Wang, 1996). This was supported by herbage $\mathrm{S}$ analysis where, 8 months after application, herbage $\mathrm{S}$ contents in the high rates of FBC ash treatments (6616 and $26462 \mathrm{~kg} \mathrm{ha}^{-1}$ ) were significantly higher than the control. Hill and Lamp (1980) demonstrated that in Australian soils, FA released magnesium $(\mathrm{Mg})$ at rates comparable with established $\mathrm{Mg}$ fertilizers.

A number of studies have examined the value of CCPs in the immobilization of P (Cheung and Venkitachalam, 2000; Stout et al., 2003; McDowell, 2004 \& 2005; Table 5). Loss of $\mathrm{P}$ through leaching and surface runoff, especially in sandy soils is a major environmental issue in many countries including Australia, resulting in the eutrophication of surface waters. For example, concentrations of $\mathrm{P}$ in runoff from agricultural catchments in southern Australia are high and well above national and international limits (Cox et al., 2005). They argue that $\mathrm{P}$ loss is a serious problem in most parts of Australia due to its unique soil (sandy texture) and climatic (xeric; i.e., strong seasonal wetting and drying cycles) conditions. Cheung and Venkitachalam (2000) reported that coarse, sandy soil such as those found in Perth, Western Australia, exhibit low attenuation capabilities for $\mathrm{P}$ during effluent infiltration.
Various CCP sources including FA and BA have shown potential as soil amendments to decrease soil inorganic $\mathrm{P}$ solubility. For example, Stout et al. (2000) reported that FBC ash has consistently reduced concentrations of water-soluble $P$ in a number of soils with high concentration of soluble $\mathrm{P}$. They found that amendment with FBC ash resulted in a shift from readily available resin $\mathrm{P}$ and less available $\mathrm{NaOH}-$ extractable $\mathrm{Fe}$ and $\mathrm{Al}$-bound $\mathrm{P}$ fractions to $\mathrm{HCl}$-extractable Ca-bound $\mathrm{P}$, which can be attributed to their neutralizing capacity. However, considering the high treatment rates $\left(22\right.$ tons $\left.\mathrm{ha}^{-1}\right)$ required to significantly reduce readily available $\mathrm{P}$ in soils, Codling et al. (2002) suggested that FBC ash may not be suitable for field application to sequester $\mathrm{P}$ in high $\mathrm{P}$ soils.

The FBC ash has also been tested in a number of studies to reduce solubility and mobility of $\mathrm{P}$ in soils with high $\mathrm{P}$ concentration and in P-rich organic wastes (Codling et al., 2002; Dou et al., 2003). In a packed column leaching study involving dairy manure, Elrashidi et al. (1999) reported that $\mathrm{P}$ in leachate in FBC ash treated column was reduced by more than $80 \%$ compared with the control treatment containing dairy manure only. In a laboratory incubation and extraction study, Dou et al. (2003) found that FBC ash applied at a rate of $400 \mathrm{~g} \mathrm{~kg}^{-1}$ reduced readily soluble $\mathrm{P}$ by $50-60 \%$ in P-rich manures including dairy, swine and broiler litter.

Seshadri et al. (2009) compared the effect of various sources of CCPs including FA, FBC and FGD ashes on $\mathrm{P}$ sorption in a variable charge soil. The increase in $\mathrm{P}$ sorption with the addition of CCPs is attributed to an increase in soil pH (Figure-2) and an increase in the concentration of aluminium (Al), Iron 
(Fe) and $\mathrm{Ca}$ in soil solution resulting in the formation of insoluble Al-P, Fe-P and Ca-P (McDowell, 2004). The decrease in $\mathrm{P}$ sorption with increasing levels of FGD gypsum is attributed to the decrease in soil $\mathrm{pH}$. Bolan et al.
(2008) examined P leaching as affected by various liming materials including FBC ash in a variable charge soil (Table 6). FBC ash decreased both bioavailable $\mathrm{P}$ as measured by Olsen $\mathrm{P}$ and leaching of $\mathrm{P}$.

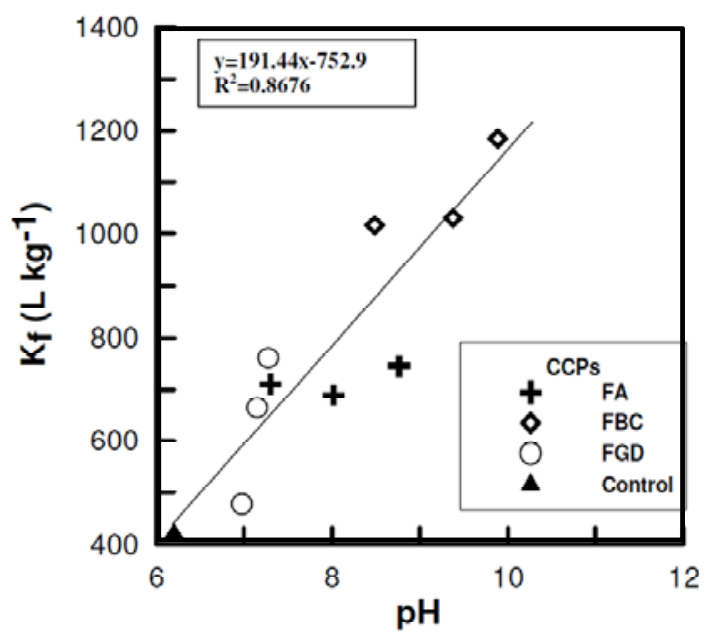

Figure 2. The relationship between soil $\mathrm{pH}$ and increase in phosphate sorption (as measured by distribution coefficient - Kf) as affected by various Ca containing soil amendments.

Table 6. Effect of various liming materials on bioavailable $\mathrm{P}$ and leaching of $\mathrm{P}$.

\begin{tabular}{lcccc}
\hline Treatment & CCE (\%)* & Rate $\left(\mathbf{k g ~ h a}^{-\mathbf{1}}\right)$ & Olsen $\mathbf{P}\left(\mathbf{m g ~ k g}^{\mathbf{- 1}}\right)$ & Leaching $\left(\mathrm{kg} \mathrm{ha}^{\mathbf{- 1}}\right)$ \\
\hline Control & - & & 165 & 37.65 \\
FBA & 42 & 600 & 35.2 & 4.52 \\
Dolomite & 114 & 220 & 28.6 & 3.48 \\
Lime stone & 100 & 250 & 15.4 & 2.85 \\
\hline
\end{tabular}

However, Mc Dowell (2004) observed increased $\mathrm{P}$ losses in New Zealand pasture soils when soil $\mathrm{pH}$ was raised with the application of FBC ash which has been attributed to the solubilisation of organic $\mathrm{P}$ due to free $\mathrm{CaO}$ in this ash by-product. He consequently concluded that ash could be useful as a supplement or alternative to lime in cropping soils where the $\mathrm{pH}$ is commonly maintained at a higher level and may, in these soils, prove beneficial in mitigating $\mathrm{P}$ loss (McDowell, 2005). Similarly, although most CCPs contain insignificant $\mathrm{N}$ 
amount, application of CCPs with organic amendments such as biosolids has been shown to increase the mobilization of $\mathrm{N}$ by inducing the mineralization of organic N (Stuczynski et al., 1998).

\section{Heavy metals}

Principally, the amount of trace elements (including heavy metals) in CCPs, excluding $\mathrm{B}$ is found within the range actually present in soils (Table 4). For example, Korcak and Kemper (1993) observed no phytotoxic effects of micronutrients when FBC ash was used as a liming source even at very high rates. However, the availability of micronutrients to plants depends not only on the amounts applied in FBC ash, but also on the soil properties and the specific crop being grown.

Although B concentrations in most CCPs (Table 4) are higher than those found in most soils, it is not toxic in most agricultural soils, unless supplied in excessive amounts by fertilizers. Wang (1996) reported that high application rate of FBC ash (up to $19,185 \mathrm{~kg} \mathrm{ha}^{-1}$ ) in a field trial had not induced visual symptom of B toxicity in a white clover and ryegrass dairy pasture in a peat soil. However, Clark et al. (1999) reported that a soil mixed with more than $0.5 \%$ FBC ash resulted in significant dry matter reduction of maize in a pot experiment due to B toxicity. Crews and Dick (1998) observed B toxicity symptoms in plant tissue when red oak is grown in soil applied with FGD ash at two times or higher the lime requirement rate. Therefore, care should be taken when applying CCPs with high levels of B to sensitive crops such as cherry, peach, lupin, and kidney bean, especially when these crops are growing on sandy soils.
Stout et al. (2000) reported that the heavy metal content in CCPs is comparable to that of more traditional agricultural soil amendment products, such as lime and gypsum. In addition, the oxide form of heavy metals in FBC ash makes them much less available to plants than the organic forms in sewage sludge. However, any increase in the quantity or availability of these metals in soils should be carefully monitored using appropriate soil tests.

The value of CCPs as a viable option in immobilizing heavy metals in contaminated soils has been examined in many studies. For example, Ciccu et al. (2001) conducted a study using soils from an Italian mine site contaminated severely with heavy metals and showed decreased levels of heavy metals in percolating water from fly ash mixed soil, indicating that fly ash in such soils can lead to immobilization of heavy metal ions.

Kumpiene et al. (2007) demonstrated reduced leaching of $\mathrm{Cu}$ and $\mathrm{Pb}$ from contaminated soil using coal fly ash and peat as soil amendments. They observed that the amendments reduced the exchangeable metal forms, likely because of the formation of new mineral $\mathrm{Cu}$ - and $\mathrm{Pb}$-bearing phases and the enhanced metal sorption due to increased amount of sorptive sites. They also observed reduced metal uptake by plants and reduced soil toxicity to microorganisms. This was attributed to the rise of soil $\mathrm{pH}$ and the lowered metal mobility due to fly ash additions.

Stehouwer et al. (1995) observed that FBC ash reduced leachate concentrations of $\mathrm{Al}, \mathrm{Fe}, \mathrm{Mn}$ and $\mathrm{Zn}$ that are frequently phytotoxic in acid soils. Decreased solubility and mobility of these metals would also improve surface and drainage water quality. 


\section{CONCLUSIONS}

The recycling of CCPs into construction and agricultural related applications can reap substantial environmental benefits. These include:

- Waste stream reduction and associated reductions in requirements for landfill.

- Contribution to the conservation of resources such as gypsum, limestone and natural gas which would otherwise be used in cement production.

- Reduction in Greenhouse Gas (GHG) emissions from cement production of almost 1 tonne of $\mathrm{CO}_{2}$ per tonne of cement.

- Decrease in fertilizer application resulting from reduced losses

Land application of CCPs affects the bioavailability of nutrients and heavy metals by both acting as their source and sink in soils. Some of the CCPs are rich in $\mathrm{S}$ and $\mathrm{Ca}$ thereby acting as a source of these nutrients. They also control the transformation of $\mathrm{N}$ and $\mathrm{P}$ through immobilization and mineralization reactions. Similarly, CCPs can act as a source of heavy metals such as B and affect their reactions by altering soil solution chemistry including $\mathrm{pH}$ and ionic strength. Thus, CCPs can be used to manage the bioavailability of nutrients and heavy metals, thereby enhancing soil chemical fertility and mitigating metal contaminated soils.

\section{REFERENCES}

Adriano, D. C., Page, A. L., Elseewi, A. A. Chang, A. C., Straughan, I. 1980. Utilization and disposal of fly ash and other coal residues in terrestrial ecosystems: A review. J. Environ. Qual. 9, 333-344.
Adriano, D. C., Weber, J., Bolan, N. S., Paramasivam, S., Bon-Jun Koo, Sajwan, K. S. 2002. Effects of high rates of coal fly ash on soil, Turfgrass and ground water quality. Water Air Soil Poll. 139, 365-385.

Adriano, D. C., Wenzel, W. W., Vangronsveld, J., Bolan, N. S. 2004. Role of assisted natural remediation in environmental cleanup. Geoderma 122, 121-142.

Ahn, C., Mitsch, W. J. 2001. Chemical Analysis of Soil and Leachate from Experimental Wetland Mesocosms Lined with Coal Combustion Products. J. Environ. Qual. 30, 1457-1463.

Alexander, R. R., Alexander, A. 2000. Bioavailability of genotoxic compounds in soil. Environ. Sci. Technol. 34, 1589-1593.

Alva, K., Paramasivam, S., Prakash, O., Sajwan, K. S., Ornes, W. H., Van Clief, D. 1999. Effects of fly ash and sewage sludge amendments on transport of metals in different soils. In: K. S. Sajwan A. K. Alva, R. F. Keefer (eds). Biogeochemistry of Trace Elements in Coal and Coal Combustion By-products, Kluwer Academic/Plenum Publishers, New York, pp: 207-222.

ADAA. 2008 Annual Membership Survey Results, January - December 2008. Ash Development Association of Australia, pp: 2-3.

ADAA. 2009. Ash Development Association of Australia: http://www.adaa.asn.au/utilisations.htm.

ASTM C204. 1994. Test Method for Fineness of Portland Cement by Air Permeability Apparatus. American Society for Testing and Materials. Annual Book of ASTM Standards, West Conshohocken, Pennsylvania.

Bhattacharya, S. S., Chattopadhyay, G. N. 2004. Transformation of nitrogen during vermicomposting of fly ash. Waste Manage. Res. 22, 488-491.

Bilodeau, A., Malhotra, V. M. 2000. Highvolume fly ash system: Concrete solution for sustainable development. ACI Mater. J. 97(1), 41-48.

Bolan, N. S., Naidu, R., Wang, H. 2007. Utilization of coal combustion products (CCPs) for environmental remediation. In: Y. Zhu, N Lepp, R. Naidu (eds) Biogeochemistry of trace elements: environmental protection, remediation and human health. Tsinghua University Press, Beijing. Developments in Science, pp: 352-353. 
Carlson, C. L., Adriano, D. C. 1993. Environmental impacts of coal combustion residues. J. Environ. Qual. 22, 227-247.

Chabbi, A., Rumpel, C. 2004. Chemical composition of organic matter in extremely acid, lignite-containing lake sediments impacted by fly ash contamination. J. Environ. Qual. 33, 628636.

Chen, L., Dick, W. A., Nelson, S. 1995. Flue Gas Desulfurization Products as Sulfur Sources for Alfalfa and Soybean. Agron. J. 97, 265-271.

Chen, L., Ramsier, C., Bigham, J., Slater, B., Kost, D., Lee Y., Dick, W. 2008. Oxidation of FGD-CaSO 3 and effect on soil chemical properties when applied to the soil surface. Fuel $88,1167-1172$

Cheung, K. C., Venkitachalam, T. H., Scott, W. D. 1994. Selecting soil amendment materials for removal of phosphorus. Water Sci. Technol. 30, 247-256.

Cheung, K. C., Venkitachalam, T. H. 2000. Improving phosphate removal of sand infiltration system using alkaline fly ash. Chemosphere 41, 243-249.

Chugh, Y., Patwardhan, A., Munish, S., Botha, F. 2006. Development of construction materials using sulfite-rich scrubber sludge and fly ash Fuel 85, 2323-2329.

Ciccu, R., Ghiani, Peretti, R., Serci, A., Zucca, A. 2001. Heavy metal Immobilisation using Fly ash in Soils Contaminated by Mine Activity. Internation Ash Utilisation Symposium. www.flyash.info.

Clark, R. B., Zeto, S. K., Ritchey, K. D., Baligar, V. C. 1999. Boron accumulation by maize grown in acidic soil amended with coal combustion products. Fuel 78, 179-185.

Crews, J. T., Dick, W. A. 1998. Liming acid forest soils with flue gas desulfurization byproduct: Growth of Northern Red Oak and leachate water quality. Environ. Pollut. 103, 5561.

Codling, E. E., Mulchi, C. L., Chaney, R. L. 2002. Biomass yield and phosphorus availability to wheat grown on high phosphorus soils amended with phosphate inactivating residues. III. Fluidized bed coal combustion ash. Commun. Soil Sci. Plant Anal. 33, 1085.
Cox. J. W., Varcoe, J., Chittleborough, D. J., Van Leeuwen, J. 2005. Using Gypsum to Reduce Phosphorus in Runoff from Subcatchments in South Australia. J. Environ. Qual. 34, 2121-2128.

Dao, T. H. 1999. Coamendments to modify phosphorus extractability and nitrogen/phosphorus ratio in feedlot manure and composted manure. J. Environ. Qual. 28, 11141121 .

Dou, Z., Zhang, G. Y., Stout, W. L., Toth, J. D., Ferguson, J. D. 2003. Efficacy of alum and coal combustion by-products in stabilizing manure phosphorus. J. Environ. Qual. 32, 14901497.

El-Mogazi, D., Lisk, D. J., Weinstein, L. H. 1988. A review of physical, chemical, and biological properties of fly ash and effects on environmental ecosystems. Sci. Total Environ. 74, 1-37.

EIrashidi, M. A., Baligar, V. C., Korcak, R. F., Persaud, N., Ritchey, K. D. 1999. Chemical composition of leachate of dairy manure mixed with fluidized bed combustion residue. J. Environ. Qual. 28, 1243-1251.

Fernández-Turiel, J. L., deCalvalho, W. Cabanas, M., Querol, X., López-Soler, A. 1994. Mobility of heavy metals from coal fly ash, Environ. Geol. 23, 264-270.

Gitari, M. W., Petrik, L. F., Etchebers, O., Key, D. L., Iwuoha, E., Okujeni, C. 2006. Treatment of acid mine drainage with fly ash: removal of major contaminants and trace elements. J. Environ. Sci. Health A: Tox. Hazard. Subst. Environ. Eng. 41, 1729-1747.

Gómez, D. M., Dos Santos, Fujiwara, F., Polla, G., Marrero, J., Dawidowski, L., Smichowski, P. 2007. Fractionation of metals and metalloids by chemical bonding from particles accumulated by electrostatic precipitation in an Argentine thermal power plant. Microchem. J. 85, 276-284.

Gupta, D. K., Rai, U. N., Tripathi, R. D. Inouhe, M. 2002. Impacts of fly-ash on soil and plant responses. Plant Res. 115, 401-409.

Heidrrich, C. 2003. Ash utilization - an Australian Perspective. International Ash Utilization Symposium, Centre for Applied Energy Research, University of Kentucky. 
Hill, M. J., Lamp, C. A. 1980. Use of pulverised fuel ash from Victorian brown coal as a source of nutrients for a pasture species. Aust. J. Exp. Agric. Anim. Husb. 20, 377-384.

Hrudey, S. E., Chen, W., Rousseaux, C. G. 1996. Bioavailability in Environmental Risk Assessment. CRC Press, Boca Raton, FL, USA.

IEA 2003. World Coal Demand and Supply Prospects Background Paper - CIAB, Meeting with IEA Governing Board. http://www.iea.org/papers/2003/ciab_demand.pdf Jankowski, J., Ward, C. R., French, D., Groves, S 2006. Mobility of trace elements from selected Australian fly ashes and its potential impact on aquatic ecosystems. Fuel 85, 243-256.

Karapanagioti, H. K., Atalay, A. S. 2001. Laboratory evaluation of ash materials as aciddisturbed land amendments. Global Nest: the Int. J. 3, 11-21

Karayigit, A. I., Gayer, R. A. 2001 Characterization of fly ash from the Kangal power plant, Eastern Turkey. International Ash Utilization Symposium, Center for Applied Energy Research, University of Kentucky.

Kesh, S., Kalra, N., Sharma, S. K., Chaudhary, A. 2003. Fly ash incorporation effects on soil characteristics and growth and yield of wheat. Asia Pacific J. Environ. Develop. 4, 53-59.

Korcak, R. F., Kemper, W. D. 1993. Long-term effects of gypsiferous coal combustion ash applied at disposal levels on soil chemical properties. Plant Soil. 154, 29-35.

Kula, I., Olgun, A., Sevine, V., Erdogan, Y. 2002. An investigation on the use of tincal ore waste, fly ash and coal bottom ash as Portland cement replacement materials. Cement and Concrete Res. 32, 227-232.

Kumpiene, J., Lagerkvist, A., Maurice, C. 2007. Stabilization of $\mathrm{Pb}$ - and $\mathrm{Cu}$-contaminated soil using coal fly ash and peat. Environ. Pollut. 145, 365-373.

Kurita, M., Nomura, T. 1998. Highly-flowable steel fiber-reinforced concrete containing fly ash In: V. M. Malhotra, Editor, Am. Concr. Inst. SP $178,159-175$.
Lee, Y. B., Ha, H. S., Lee, K. D., Park, K. D. Cho, J. S., Kim, P. J. 2003. Evaluation of use of fly ash-gypsum mixture for rice production at different nitrogen rates. Soil Sci. Plant Nutr. 49, 69-76.

Lee, Y. B., Bigham, J. M., Dick, W. A., Jones, F. S., Ramsier, C. 2007a. Influence of soil $\mathrm{pH}$ and application rate on the oxidation of calcium sulfite derived from flue gas desulfurization. J. Environ. Qual. 36, 298-304.

Lee, C. H., Lee, Y. B., Lee, H., Kim, P. J. 2007b. Reducing phosphorus release from paddy soils by a fly ash-gypsum mixture. Bioresour. Technol. 98, 1980-1984.

Mattigod, S. V., Rai, D., Eary, L. E., Ainsworth, C. C. 1990. Geochemical factors controlling the modilization of inorganic constituents from fossil fuel residues: I. Review of the major elements. J. Environ. Qual. 19,188201.

McDowell. R. W. 2004. The effectiveness of Industrial by-products to stop phosphorus loss from a Pallic soil. Aust. J. Soil Res. 42, 755-761.

McDowell, R. W. 2005. The effectiveness of coal fly-ash to decrease phosphorus loss from grassland soils. Aust. J. Soil Res. 43, 853-860.

McDowell, R. W., Sharpley, A. N., Bourke, W. 2008. Treatment of drainage water with industrial by-products to prevent phosphorus loss from tiledrained land. J. Environ. Qual. 37, 1575-1582.

Miravet, R., López-Sánchez, J. F., Rubio, R. 2006. Leachability and analytical speciation of antimony in coal fly ash. Anal. Chim. Acta 576, 200-206.

Naidu, R., Bolan, N. S., Megharaj, M., Juhasz, A. L., Gupta, S. K., Clothier B. E., Schulin, R. 2008. Chemical Bioavailability in Terrestrial Environments. In: A. E. Hartemink, A. B McBratney, Ravendra Naidu (eds). Chemical Bioavailability in Terrestrial Environment. Elsevier, Amsterdam. Dev. Soil Sci. 32, 1-6.

O'Reilly, S. E., Sims, J. T. 1995. Phosphorus adsorption and desorption in a sandy soil amended with high rates of coal fly ash. Comm. in Soil Sci. Plant Anal. 26, 2983 2993. 
Page, A. L., Elseewi, A. A., Straughan, I. 1979. Physical and Chemical properties of fly ash from coal-fired power plants with references to environmental impacts. Residue Rev. 71, 83-120.

Pathan, S. M., Almore, L. A. G., Colmer, T. D. 2003. Reduced leaching of nitrate, ammonium, and phosphorous in a sandy soil by fly ash amendment. Aust. J. Soil Res. 40(7), 1201-1211.

Peng, M., Ruan, X. G., Chen, X. M., Xu, J. W., Jiang, Z. C. 2004. Study on both shape and chemical composition at the surface of fly ash by scanning electron microscope, focussed ion beam, and field emission-scanning electron microscope. Chinese J. Anal. Chem. 32(9), 1196-1198.

Punshon, T., Adriano, D. C., Weber, J. 2002. Restoration of drastically eroded land using coal fly ash and poultry biosolid. Sci. Total Environ. 296, 209-225.

Punshon, T., Seaman, J. C., Sajwan, K. S. 2003. The production and use of coal combustion products. In: K. S. Sajwan, A. K. Alva, R. F Keefer (eds). Chemistry of Trace elements in Fly ash. Kluwer Academic/Plenum Publishers, New York, pp: 1-11.

Qafoku, N. P., Kukier, U., Sumner, M. E., Miller, W. P., Radcliffe, D. E. 1999. Arsenate displacement from fly ash in amended soils, Water Air Soil Poll. 114, 185-198.

Sajwan, K. S., Paramasivam, S., Alva, A. K. 2007. Effects of different rates of fly ash and sewage sludge mixture amendments on cation availability and their leachability. J. Environ. Sci. Heal. 42, 1155-1160.

Sen, P. K., Saxena, A. K., Bhowmick, S. 1997. In: V.S.V. Raju, M. Dutta, V. Seshadri, V. K. Agarwal, V. Kumar (eds). Ground Water Contamination Around Ash Ponds and Ash Disposal System, Narosa publications, New Delhi, pp: 326-342.

Seoane, S., Leiros, M. C. 2001. Acidificationneutralization processes in a lignite mine spoil amended with fly ash or limestone. J. Environ. Qual. 30, 1420-1431.

Seshadri, B., Wickremaratne, C., Bolan, N. S., Brodie, K., Naidu, R. 2009. Enhancing Phosphorus Retention Capacity of soils using Coal Combustion Products. In Clean up 2009 Conference. September 2009. Adelaide, Australia.
Sharma, S. K., Kalra, N. 2006. Effect of fly ash incorporation on soil properties and productivity of crops: A review. J. Sci. Ind. Res. 65, 383-390.

Singh, S. N., Kulshreshtha, K., Ahmad, K. J. 1997. Impact of fly ash soil amendment on seed germination, seedling growth and metal composition of Vicia faba. L. Ecol. Eng. 9, 203208.

Sinha, K. S., Basu, K. 1998. Mounting flyash problems in growing coal based power stationsfew pragmatic approaches towards a solution. In: C. V. J. Verma, P. K. Lal, V. Kumar, R. Lal, R. Krishnamurthy (eds). Proc. of Int. Conf. on Flyash Disposal and Utilization vol. I, Central Board of Irrigation and Power, New Delhi, India, pp: 15-27.

Soco, E., Kalembkiewicz, J. 2007a. Investigations of sequential leaching behaviour of $\mathrm{Cu}$ and $\mathrm{Zn}$ from coal fly ash and their mobility in environmental conditions. J. Hazard Mater. 145, 482-487.

Soco, E., Kalembkiewicz, J. 2007b. Investigations on $\mathrm{Cr}$ mobility from coal fly ash. Fuel 88, 1513-1519.

Srivastava, R. K. 2000. Controlling $\mathrm{SO}_{2}$ Emissions - A Review of Technologies. Prepared for the U.S. Environmental Protection Agency, EPA/600/R-00/093.

Stehouwer, R. C., Sutton, P., Fowler, R. K., Dick, W. A. 1995. Minespoil amendment with dry flue gas desulfurization by-products: Element solubility and mobility. J. Environ. Qual. 24,165174

Stehouwer, R. C., Sutton, P., Dick, W. A. 1996. Transport and plant uptake of soil-applied dry flue gas desulphurization by products. Soil Sci. 161(9), 562-574.

Stokes, J. D., Wilkinson, A., Reid, B. J., Jones, K. C., Semple, K. T. 2005. Prediction of PAH biodegradation in contaminated soils using an aqueous hydroxypropyl- beta-cyclodextrin extraction technique. Environ. Toxicol. Chem. $24,1325-1330$

Stout, W. L., Priddy, W. E. 1996. Use of flue gas desulphurisation (FGD) by-product gypsum on alfalfa. Commun. Soil Sci. Plant Anal. 27, 2419 . 
Stout, W. L, Sharpley, A. N., Pionke, H. B. 1998. Reducing soil phosphorus solubility with coal combustion by-products. J. Environ. Qual. 27, 111-118.

Stout, W. L., Sharpley, A. N., Landa, J. 2000. Effectiveness of coal combustion by-products in controlling phosphorus export from soils. J. Environ. Qual., 4, 1239-1244.

Stout, W. L., Sharpley, A. N., Weaver, S. R. 2003. Effect of amending high phosphorus soils with flue-gas desulfurization gypsum on plant uptake and soil fractions of phosphorus. Nutr. Cycl. Agroecosys. 67(1), 21-29.

Stuczynski, T. I., McCarthy, G. W., Wright, R. J. 1998. Impact of coal combustion product amendments on soil quality: I. Mobilization of soil organic nitrogen. Soil Sci. 163, 952-959.

Terman, G. L., Kilmer, V. J., Hunt, C. M., Buchanan, W. 1978. Fluideised bed boiler waste as a source of nutrients and lime. J. Environ. Qual. 7, 147-151.

Tiwari, S., Kumari, B., Singh, S. N. 2008 Evaluation of metal mobility/immobility in fly ash induced by bacterial strains isolated from the rhizospheric zone of Typha latifolia growing on fly ash dumps. Bioresour. Technol. 99, 13051310.

Topaç, F. O., Başkaya, H. S., Alkan, U. 2008. The effects of fly ash incorporation on some available nutrient contents of wastewater sludges. Bioresour. Technol. 99(5), 1057-1065.

Tripathi, R. D., Dwivedi, S., Shukla, M. K., Mishra, S., Srivastava, S., Singh, R., Rai, U. N., Gupta, D. K. 2008. Role of blue green algae biofertilizer in ameliorating the nitrogen demand and fly-ash stress to the growth and yield of rice (Oryza sativa L.) plants. Chemosphere 70, 19191929.

Vincini, M., Carini, F., Silva, S. 1994. Use of alkaline fly ash as an amendment for swine manure, Bioresour. Technol. 49, 213-222.

Wang, H. L., Hedley, M. J., Bolan, N. S. 1994. Chemical properties of fluidised bed boiler ash relevant to its use as a liming material and fertiliser. NZ J. Ag. Res. 38, 249-256.

Wang, H. L. 1996. Potential uses of fluidised bed boiler ash (FBA) as a liming material, soil conditioner and sulphur fertilizer. $\mathrm{PhD}$ thesis, Massey University, Palmerston North, New Zealand.
Wang, H., Bolan, N. S., Hedley, M. J., Horne, D. J. 2006. Potential uses of fluidized bed boiler ash (FBA) as a liming material, soil conditioner and sulfur fertilizer. In: Coal combustion byproducts and environmental issues. K. S. Sajwan, I. Twardowska, T. Punshon, A. K. Alva (eds). Springer Publishers, New York, USA, pp: 202-215.

Wang, S. J., Chen, C. H., Xu, X. C., Li, Y. J. 2008. Amelioration of alkali soil using flue gas desulfurization byproducts: Productivity and environmental quality. Environ. Pollut. 151, 200204.

WCI 2008. Coal facts 2008. World Coal Institute. Sourced on 27/01/2010. http: //www.worldcoal.org/resources/coal-statistics/.

WCI 2009. What is coal? World Coal Institute. Sourced on 27/01/2010. http://www.worldcoal.org/coal/what-is-coal/

WEC 2007. Survey of Energy Resources. World Energy Council. Sourced on 27/01/2010. http://www.worldenergy.org/publications/survey _of_energy_resources_2007/coal/628.asp

Wong, J. W. C., Fang, M., Li, G. X., Wong M. H. 1997. Feasibility of co composting coal ash residues with sewage sludge. Environ. Technol. 18, 563-567.

Wright, R. J., Codling, E. E., Stuczynski, T., Siddaramappa. R. 1998. Influence of soilapplied coal combustion by-products on growth and elemental composition of annual ryegrass. Environ. Geochem. Hlth 20, 11-18.

Xu, J. Z., Zhou, Y. L., Chang, Q., Qu, H. Q. 2006. Study on the factors of affecting the immobilization of heavy metals in fly ash-based geopolymers. Mater. Lett. 60, 820-822.

Yunusa, I. A. M., Eamus, D., DeSilva, D. L., Murray, B. R., Burchett, M. D., Skilbeck, G. C. Heidrich, C. 2006. Fly ash: An exploitable resource for management of Australian agricultural soils. Fuel 85, 2337-2344.

Zhang, W., Brown, G. O., Storm, D. E., Zhang, H. 2008. Fly-ash-amended sand as filter media in bioretention cells to improve phosphorus removal. Water Environ. Res. 80(6), 507-516. 